\title{
British government reviews its plans for student loans
}

London

THE British government is being forced to rethink its plan for the introduction of loans to students in higher education to replace the maintenance grant they receive at present. The Department of Education and Science was warned last week that the administrative costs of the proposed system will outweigh the savings. Banks and building societies, which the government planned should administer the scheme, are now reluctant to commit themselves without reassurance that the government will meet some of these costs.

In a paper written for the Department

\section{Clash over salaries}

\section{London}

THE dispute over a salary increase for academic staff in British universities turned into a crisis this week as staff began a boycott of the examination process to put pressure on the vice-chancellors to make an offer for last year. Discussions between the Association of University Teachers (AUT) and the Committee of Vice-Chancellors and Principals (CVCP) have now dragged on for a year.

Both parties agree that a salary increase

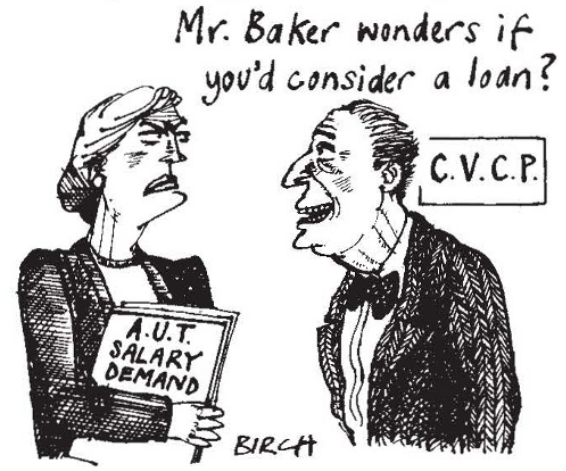

is necessary, but the CVCP says there is no money to finance it; any offer would have to be so low as only to inflame the situation, and anything else would risk bankrupting some universities, it says. The AUT insists that a modest increase is affordable. Meanwhile, the CVCP is trying to persuade the government to provide extra cash for a salary increase for 1989-90. It says that although pay has gone up by about 8 per cent a year over the past three years, it stands at less than 80 per cent of its value ten years ago.

Under the terms of the boycott, the 30,000 members of the AUT are expected not to set or mark examination papers or to invigilate exams. The CVCP has warned staff that such action constitutes a serious breach of contract. of Education, Nicholas Barr of the London School of Economics says that the annual administration costs of the scheme would be $£ 100$ per student, resulting in a total annual cost within 15-20 years of $£ 250$ million. The government's policy paper on loans, published last November, fails to take account of these costs and foresees annual savings of $£ 230$ million once the scheme is established. An alternative method of repayment of loans is now under consideration. This method, which involves an addition to graduates' national insurance contributions, would be administratively very simple and cheap, says Barr. And because evasion of repayment would be more difficult, resulting losses would be no more than 10 per cent of the total as opposed to the predicted 25 per cent losses under the original plan.

Outlining his vision for higher education in the next 25 years, the Secretary of State, Kenneth Baker, said at a conference last week that the British system should be expanded along the lines of that in the United States (see page 102). The present British system in which higher education is dominated by the role of the state would remain for the foreseeable future, he said. But continued dependence on public funds would hinder moves towards greater autonomy and diversity. Baker's vision of an expanded higher education system includes an influx of older students, women and members of ethnic minorities.

Overseas students in British universities face steep increases in fees after the Committee of Vice-Chancellors and Principals (CVCP) raised the prices for next year's courses by 10 per cent. At a time when countries such as Australia and Canada are trying hard to attract a bigger share of the world market in students, Britain is risking losing more overseas students, according to Andrew Mascheter, director of the UK Council for Overseas Student Affairs.

The CVCP this year took over the role of pricing courses from the University Grants Committee. And instead of setting a minimum price, it set what it calls a form of "recommended retail price", allowing universities to set higher or lower prices as they choose. Although it is unlikely that universities will lower prices in the near future, price-cutting could take place as competition between universities for overseas students becomes more aggressive. Recruiters for overseas students at the universities are worried that this might happen and say that if prices drop then standards too will drop.

Christine McGourty
Surprise candidate

Academician Andrei Sakharov has been nominated as a candidate in the forthcoming Soviet parliamentary elections - the first to be held on a multicandidate basis. His nomination was approved at a meeting at the Pavlov Institute of Physiology of the Soviet Academy of Sciences in Leningrad on 5 January. Sakharov was not present at the meeting but his supporters say that "his opinions and civic standing are well enough known for him to be regarded as capable of defending the cause of perestroika and renewal of Soviet society".

V.R.

\section{New Wolfson awards}

UNDER a novel awards scheme, the Wolfson Foundation is making grants not tied to specific research projects; instead, they are made to researchers so that they can employ additional staff and buy equipment. Eighty-five grants, worth $£ 6$ million, were announced last week. A further $£ 4$ million will be spent in 1991 .

C.McG.

\section{Super consortia plans}

\section{Washington}

A special advisory committee formed to make recommedations to the White House on how best to realize the commercial possibilities of the new class of high-temperature superconductors last week released its conclusions. The so-called 'wise men's' committee suggests creating about half a dozen Superconductivity Consortia along the lines of the NSF's Science and Technology Centers, bringing together universities, industry and government laboratories. The committee, chaired by Ralph Gomory of IBM, also suggests there is extra research capacity that could help the commercialization effort. J.P. Synchrotron go-ahead

THE European Synchrotron Radiation Facility (ESRF) has finally been given the green light, 14 years after the European Science Foundation set up its first working party to investigate its feasibility. Representatives of the 11 participating countries met in Paris in December to sign the documents approving the project. ESRF, which will cost FF2,600 million ( $\$ 434$ million), will take 6 years to build and will be the world's most powerful synchrotron radiation facility. The first beam line will be ready on the Grenoble site in 1994 and the full 30 beam lines by 1998 .

P.C.

\section{Nature movements}

Alun Anderson, Washington Editor, will be based in the Tokyo office from 18 January to 18 March. Joseph Palca, Washington News Editor, will act in his stead in the interval. David Swinbanks, Tokyo correspondent, will be based in the Washington office during the same period. John Maddox, Editor, will be based in Washington from 1 to 28 February. 